\title{
中国・日本・欧州の被験者による河川景観の認識・評価と注視特性に関する分析 STUDY ON RECOGNITION AND FIXATION BEHAVIOR FOR RIVER-LANDSCAPE BY THE SUBJECTS OF CHINESE, JAPANESE AND EUROPEAN
}

\author{
金 華*, 村川三郎**, 西名大作*** \\ Hua JIN, Saburo MURAKAWA and Daisaku NISHINA
}

\begin{abstract}
An experiment used eye camera (EMR-7) was carried out to study cultural influences on visual scanning. Three subjects groups (Chinese foreign students, Japanese students, European foreign students, and all the subjects lived in Hiroshima or Higashi-Hiroshima city) were tested by presentation of 8 peaces of river-landscape. Data of the fixation behavior were measured, when the subjects were looking at freely and evaluating the landscapes. The similar tendency was appeared on fixation behavior during looking at the landscape, as they like. However, if any questions were given before scan the landscape, there was the difference among the fixation behavior of the three groups. By using discriminant analysis with fixation and evaluation, the results were showed that the different visual behaviors affect evaluating landscape too because of the subject's different cultural background.
\end{abstract}

\section{Keywords: Cross-culture, Eye-movement, Eye Camera, Psychological Evaluation, Component Element, River-Landscape 異文化、眼球運動、アイカメラ、心理的評価、構成要素、河川景観}

1. 序

景観や環境の評価にあたって、評価者をその出身国という単位で 分類するなら、それぞれの国ごとに独特な生活習慣や、自然環境の 様相などの地理的条件、あるいは経済や政策方針などさまざまな社 会・文化的背景の違いが内在することによって、得られたグループ はそれぞれ異なる認識・評価のプロセスを有する集団とみなすこと ができる。このような観点から、筆者らは国という集団の違いを評 価者の個人差として取り上げ、出身国の相違を含む異文化間におけ る環境や景観評価について、一般学生や留学生を対象とした意識調 査結果から、居住地域の生活環境やみどり環境、みどり景観の評価 構造を比較し、さらに、英国・日本・中国の被験者による国内外河 川景観評価に関する実験を実施し、出身国の社会・文化的背景や、 自然環境の様相が評価に影響を及ぼすことを明らかにした ${ }^{1) 、 2) 、 3) 。 ~}$

一方、景観評価を行う際には、景観に含まれる視覚情報をどのよ うに収集しているかが極めて重要であると考えられる。景観という 視覚刺激が与えられたとき、目の動きによってそれに含まれるさま ざまな情報が把握されるが、それらの情報は神経を介して脳に伝わ り、評価者の知識、経験などの記憶と照合され、最終的な判断が定 まると考えられる。このような一連の認識・評価プロセスにおいて、 眼球の動きは視覚刺激に対する探索の役割を果たしている。このよ
うなことから、藤井ら ${ }^{4)}$ は植物の色彩、古谷ら ${ }^{5)}$ は景観に含まれて

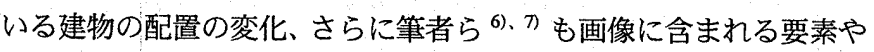
その特徵量などを报い、評価対象となる視覚刺激（景観）の物理的 特性に着目し、評価者の注視特性並びに心理的評価の特性を明らか にすることを試みてきている。

ここで、眼球運動を脳内で行われている視覚情報処理過程を反映 する外部へのパラメータと考えるなら、目の動き方は評価者のこれ までの生活経験や知識によって異なる可能性があり、さらに言えば 評価者の有する価值観や考え方も反映されるのではないかと思われ る。したがって、評価者の社会・文化的背景の違いが、注視特性を 含む景観に対する認知の仕方にも影響を及ぼす可能性が予想される。 このような考え方に基づき、筆者らは、日本人大学生と中国人留学 生を被験者として、構成要素の単純な組み合わせによって作成した 景観画像について、眼球運動の測定とともに心理的評価を求める実 験を行い、社会・文化的背景による人間側の条件の違いが心理的評 価に及ぼす影響を、注視特性の援用によって明らかにすることを試 みてきている ${ }^{8)}$

しかし、筆者らの研究を含む、これまでの研究では、眼球運動の 測定と心理的評価の回答との間に若干の時間差が存在する。いかな る質問が与えられているかによって、大脳の情報処理やその反映と
* 大連民族学院工業芸術設計系 助教授 - 博士 (工学)

** 広島大学大学院工学研究科 教授・工博

*** 広島大学大学院工学研究科 助教授・博士 (工学)
Assoc. Prof., Program of Industry Art Design, Dalian Nationalities Univ., Dr. Eng. Prof., Graduate School of Engineering, Hiroshima Univ., Dr. Eng.

Assoc. Prof., Graduate School of Engineering, Hiroshima Univ., Dr. Eng. 
しての注視特性は異なることが予想され、評価・判断がごく短時間 で行われることを考え合わせるなら、質問の提示と同時に眼球運動 測定を行うことにより、注視特性と心理的評価との直接的な対応関 倸をより明確に把握することが可能であると考えられる。また、既 報 ${ }^{8)}$ では、呈示した景観が合成画像であり、実在の景観ではないた め、より多様な構成要素を含む一般的な景観についても異なる出身 国における認知の仕方の相違を検討する必要がある。

そこで、本研究は、視覚刺激としての景観の呈示から評価・判断 を定めるにいたる一連の認識・評価プロセスについて、着目ずる要 素の異なる出身国間での相違をより明確にすることを目的に、日本、 中国、欧州の被験者に対して、一般的な国内外の河川景観を呈示し、 景観を自由に眺めさせた場合と、心理的評価を行う場合の双方につ いて眼球運動測定実験を行い、分析したものである。なお、以降本 研究では、質問項目を特に与えず、景観を自由に眺めさせる場合を 「自由観察時」、ある特定の質問を与えた上で景観を眺めさせる場合 を「評価回答時」とそれぞれ称することとする。

\section{2. 実験概要}

\section{1 実験方法}

実験は、中国人留学生 30 名、日本人大学生 30 名、欧州出身の留 学生 14 名を被験者として、2001 年 1 月〜 7 月の間に実施した。 8 種 類の国内外河川景観のスライド映像を呈示し、眼球運動の測定と併 せて 8 項目の心理的評価を求めた。実験の場所としては、広島大学 工学部の会議室（A2-713） と広島大学東千田キャンパス総合校舎 の共用研究室を使用した。実験状況を図ー1 に示す。測定に用いた アイカメラ（ナック社製 EMR－7）は、視野角で横方向 60 度、縦方 向 40 度の範囲における、被験者の視点(視線を向けている䇢所の意、 以降同じ) のXY座標値を出力するため、スライド映像の大きさを 被験者から見て横方向 30 度、縦方向 20 度となるよう、スライドプ ロジェクタ、スクリーン、被験者の位置などを決定した。

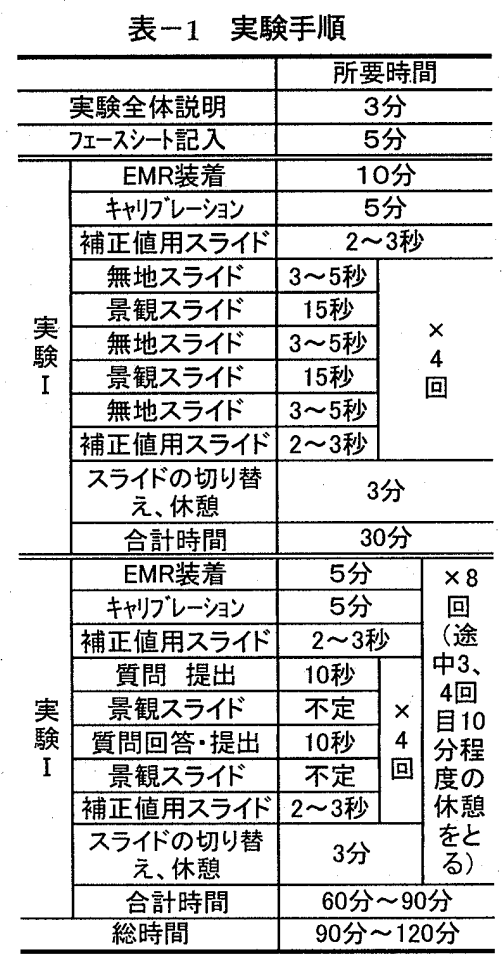

実験手順を表一1 に示す。個人特性に関するフェースシートの記 入、実験の説明と教示を行った後に、注視特性と心理的評価を求め た。前述したように、眼球運動測定は自由観察時の測定（以降実験 I と称する）と、評価回答時の測定（以降実験 II と称する）の 2 段 階に分けて行った。両実験ともに、最初アイカメラを被験者の頭に 装着し、被験者が実際見ている箇所とアイカメラによる測定点とが ほぼ一致するようにキャリブレーション作業を行った。その後、実 験 I では、 8 枚の景観を 15 秒ごとに呈示し、被験者に自由に眺めさ せ、その間の眼球運動を測定した。実験 IIでは、被験者に閉眼させ、 口頭で 1 項目の質問を提出し、予め 1 種類の景観を映写しておいたうえ で、被験者に開眼させ、その質問に対する回答に必要な時間だけ影観を 自由に眺めさせた。回答を決定次第、閉眼させ、結果を手で合図させた 注 1)。このような手順で、1 種類の景観と 1 項目の心理的評価の組み合 わせによる眼球運動測定を計 64 回行い、最終的に 8 種類の景観に対す る 8 項目の心理的評価の回答を得た。景観の呈示と質問の提出はランダ ムな順序で行った。また、被験者の疲労を考えて、8 種類の景観を呈示 するごとに休憩をとった注2)。

実験に用いた回答票の質問項目を表一2 に示す。フェースシート には被験者の属性のほか、河川に対する個人の意識やこれまでの接 触程度に関する項目、さまざまな国や地域に対する関心や経験に関 する項目が含まれている。各景観に対する評価としては、個人の皆 好や景観の物理的特性を反映する総体的 ・個別的評価 4 項目と、既 往の研究 ${ }^{3)}$ で、国別に得られたイメージ評価構造から各国に共通し て抽出された『快適性』『統一性』『躍動性』『伝統性』の 4 因子を選 定し注3)、いずれの項目についても、5 段階尺度で評価を求めた。な お、中国、欧州の被験者には、日本語で作成した回答票をそれぞれ 中訳・英訳して用いた。

実験で用いた景観写真 8 種の内容を写真 -1 に示す。これらは、 中国、日本、欧州の学生をそれぞれ被験者とすることから、欧州、 
英国、日本、中国の景観がそれぞれ同数（2 種）になるよう、既報 3) で用いた国内外河川景観の中から選定した。その際には、各国固 有の特徽がなるべく反映されていること、既報 ${ }^{3)}$ の結果から、心理 的評価傾向が極端に類似しないことなどを考慮した。

\section{2 被験者の個人属性}

被験者は、出身国以外の個人差をなるべく少なくするため、性別 は男性に限定し、各国とも、広島大学に在籍する学生を中心に選ん でいる。なお、中国人留学生と日本人大学生は 30 人程度が確保でき たが、既報 ${ }^{3)}$ と同様に英国出身の学生のみを被験者とすることが困 難であったため、図一2 に示す欧州出身の留学生 14 名を選定した。 なお、このうち2 名は広島経済大学に在籍する学生である。欧州被 験者の出身国は、欧州の中部、西部に位置する 8 力国であり、日本 や中国と比較した場合、自然環境や文化的背景などはそれら諸国で ある程度共通するものと思われる。

また、中国や欧州では、被験者を留学生としたことから、年齢や 専門、学歴は必ずしも統一的ではなく、中国は 30 代前後の大学院生 や研究生、欧州は 20 代前半と 30 代前半が 5:3 の割合で、大学院生、 研究生、聴講生が均等の割合を占めている。また、日本の被験者は なるべく留学生との年齢差が少なくなるよう学部学生を避け、20 代 前半の大学院生を中心としている。專攻分野は、日本、中国ともに、 理系が 7 割以上であるが、欧州は文系と理系がほぼ半々になった。

次に、各被験者のこれまでの海外に対する経験や河川に関する意 識についての回答結果を図一 3 に示す。『海外における経験』では、 欧州は $100 \%$ の渡航経験があるものの、距離的に卑近な「西ヨーロッ パ」や「東ヨーロッパ」「北米」の回答割合が高く、また、日本への留学 の関係から、日本の周辺である「東アジア」や「東南アジア」の回答も 多少指摘され、各国で実験を行った既報 ${ }^{3)}$ の被験者よりアジアに対 する知識がやや豊富であるといえる。日本人学生の渡航経験は半数 であるのに比して、中国ではわずか 2 割強である。両国とも自国近 辺の「東アジア」や「東南アジア」のほか、日本は「北米「西ヨーロッ

\begin{tabular}{|c|c|c|c|c|c|c|c|c|c|c|}
\hline \multicolumn{11}{|c|}{ 構成割合(\%) } \\
\hline $0 \%$ & $10 \%$ & $20 \%$ & $30 \%$ & $40 \%$ & $50 \%$ & $60 \%$ & $70 \%$ & $80 \%$ & $90 \%$ & $100 \%$ \\
\hline & & & & & & 2 & 2 & & 13 & (14) \\
\hline
\end{tabular}

Austria Poland aEngland Romania Netherlands $\square$ Germany Bulgaria E France 図一2 欧州被験者の出身国
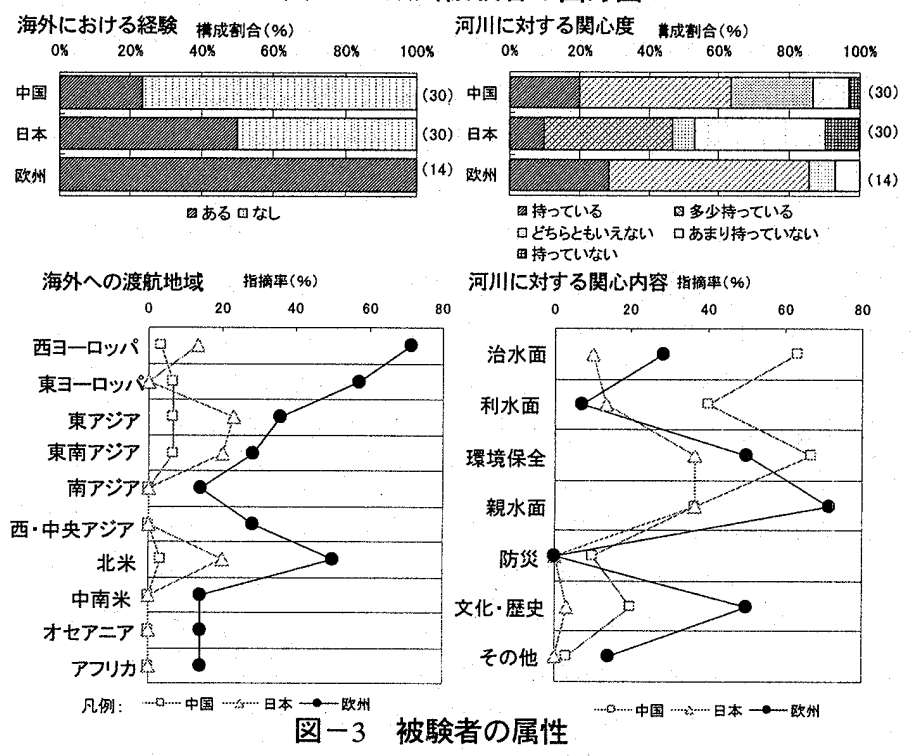

パ」、中国は「東ヨーロッパ」も若干指摘されている。

『河川に対する関心度』は、中国と日本は「多少持っている」以上 の回答がそれぞれ 6 割強、 5 割弱を占めている。また、関心の内容 としては、中国では「治水」利水」環境保全」、日本では「環境保全」 「親水面」でそれぞれ指摘の多いことがわかる。欧州では関心を「持つ ている」と「多少持っている」が 9 割弱を占め、「親水面」と「文化・歷 史」について他の 2 国より関心の高いことがわかる。

これらの結果は、中国、欧州の被験者に渡航経験がやや多いもの の、既報 ${ }^{3)}$ の被験者群とほぼ類似した傾向を示しており、既報の結 果と本研究の結果とを比較検討する上で、各国の被験者群の特性に 両者であまり差異のないことが確認できた。

\section{3. 河川景観に対する心理的評価}

\section{1 心理的評価の傾向}

8 種類の心理的評価項目については、 5 段階尺度に $1 \sim 5$ の得点を 付与し、各国ごとに平均評価得点プロフィールを求めるとともに、

景観ごとの平均評価得点に基づいて異なる 2 国間の相関係数を算出 した注4)。結果を図ー4 に示す。以下、日本、中国、英国で河川景観 の評価傾向の比較を行った既報 ${ }^{3)}$ の結果と比べて検討する。

『緑量』と『水量』では、既報と同様に、評価と直接関連する構 成要素が景観に占める面積によって、評価が左右される傾向が 3 国 とも共通にみられる。なお、本研究では、『緑量』において、河岸に 並木が整列に並んでいる「日ー2」が、「欧一2」とほぼ同程度の高評価 となる傾向が中国でみられ、緑の量だけでなく、河岸での存在形態 も考慮されているものと予想される。

『建て込み』では、建物の形状や色彩、可動物などの統一性、緑量 の多少も評価に影響している傾向が、既報と異なり、日本や欧州と同 様に中国でも共通してみられる。また、整備された河岸に整然と並 木が配置されている「日ー2」が中国と日本で高評価となり、特に日本 では「英ー 1 」英-2」でも高評価となる傾向が顕著にみられ、河岸の 整備状況も考慮される可能性がうかがえる。

『満足意識』と『快適性』では、3 国ともに、評価傾向が類似し ており、人工物の多少によって評価が左右される傾向が既報之同様 に認められた。ただし、中国では『緑量』の評価傾向とも類似して いることから、河岸における植栽の量や存在形態も考慮されている 可能性が本研究では示唆される。

『統一性』と『躍動性』でも、3 国ともに既報と同様な傾向を示 し、『統一性』は建物の意匠や材料、色彩などが協調しているかどう かにようて評価の定まる傾向がみられ、『躍動性』は可動物や人工物 の存在が評価に反映されている。なお、中国では河岸の樹木が豊か で、整然と密集した形態であれば、評価が高くなる傾向がみられ、

『緑量』の評価傾向と類似していることから、植物の存在形態や景 観全体の色彩などがより考慮され、『統一性』特に『躍動性』では他 の 2 国との差異が現れている。

『伝統性』では、中国、日本はいずれも、自国の伝統的な景観を 高く評価する傾向がみられ、自国の伝統的な文化に対する認識の高 いことが予想される。また、中国では、「欧一1」のほか「英一1」「英一 2」の評価で既報と同様に他の 2 国との差異がみられ、海外、特に欧 州に対する体験が浅いため、比較的新しい建物であっても建物様式 がヨーロッパ風であることから高く評価される可能性が示唆される。 

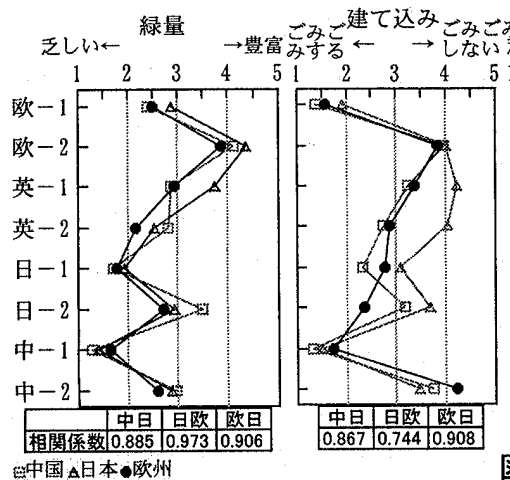

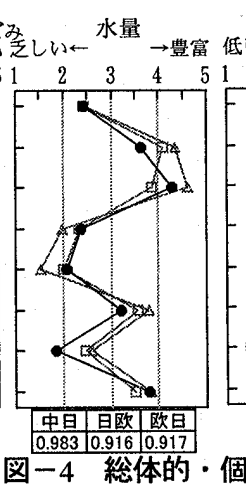

図-4 総体的
满足意識

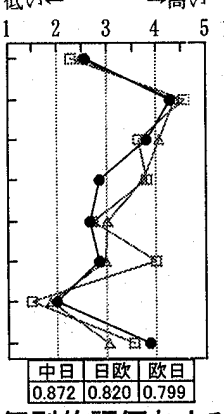

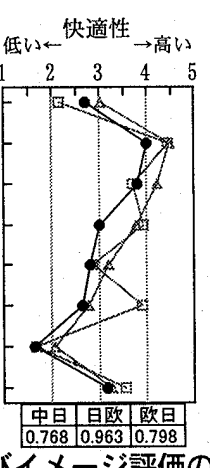

(氏丶 統一性
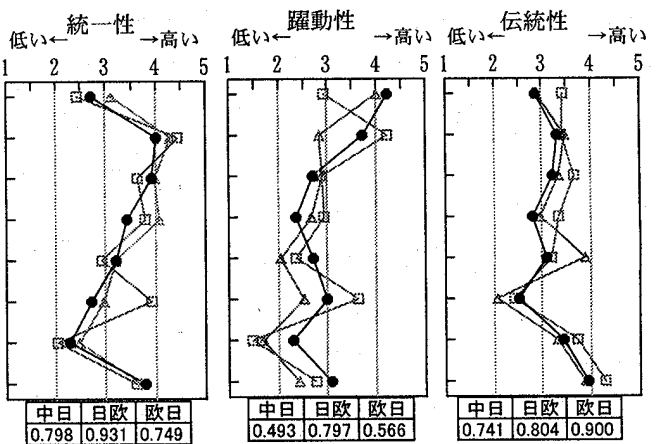

中易目欧欧
図中に付した相関係数に基づいて以上の結果を整理するなら、 『緑量』や『水量』など景観中の特定の構成要素との関連が予想さ れる項目では、いずれの 2 国間の相関係数も高く、特に日本と中国 では評価得点の差異が小さいことなど既報と同様な結果が得られた。 なお、他の項目については、既報で得られた日本と中国でより高い 類似性を示す傾向は本研究では得られず、『躍動性』以外の項目では、 3 国間でほぼ類似した傾向がみられた。これは、中国や欧州の被験 者を日本への留学生としたことから、他の国の文化に対する認識が 既報で採用した被験者より高いことが予想され、評価の差異が著し く大きくはならなかったものと考えられる。

以上から、本研究で得られた中国、日本、欧州の被験者による心理 的評価結果は、既報とほぼ同様な傾向を示しており、本研究の被験者群 は、それぞれ既報の被験者群と極端な差異はないといえる。このことか ら、各国の評価傾向の特徴が安定していることが確かめられると同時に、 本研究の被験者群を用いて、社会・文化的背景による影響を検討するこ との妥当性が確認されたものと判断でさる。

\section{2 項目間の相互関連性}

次に、心理的評価の各項目間の相互関連を検討し、3 国間の評価 傾向の差異をより明確に把握するため、8 景観をサンプルとした心 理的評価各項目間の相関行列を求めた。結果を表一 3 に示す。

3 国ともに、個人の暂好や景観の総合的評価を反映する『满足意 識』『快適性』では、『緑量』『建て込み』『統一性』との相関が共通 して認められ、景観の満足度に、各構成要素の形態や量、配置など の物理的特性が影響を及ぼしていることがうかがえる。

なお、中国では、『伝統性』を除く項目間の全体的な関連が、日 本、欧州に比べてより強く、特に『緑量』とは、総合的評価である 『満足意識』や『快適性』をはじめ多くの項目との相関がみられる。 緑被率が日本や欧洲より低い中国では注 5)、緑化など自然環境保全が国 策として重視され始めていることから、緑に対する関心が他の 2 国より 高いことが予想され、総合的評価に影響を及ぼした可能性が指摘できる。 また、欧州では、日本、中国ではみられない『伝統性』と『満足 意識』『快適性』『統一性』などとの関連がみられ、既報 ${ }^{3)}$ と同様に、 欧州出身の被験者においては、伝統性が景観の総合的評価を左右す る要因であることがここでも検証できた。

\section{4. 河川景観の認識・評価に対する注視特性}

本章では、景観の自由観察時と評価回答時の注視特性をそれぞれ把握 し、出身国間の差異について検討する。なお、本研究では、筆者らの これまでの研究成果から ${ }^{6}$, 7、、画角にして半径 1.5 度末満の円形範 囲内に 0.2 秒以上視点が留まった場合を注視点として定義する注 6)。
表-3 各心理的評価項目間の相関

\begin{tabular}{|c|c|c|c|c|c|c|c|c|}
\hline 国別 & 評価項目 & 緑量 & 建て込み & 水量 & 満足意識 & 快適性 & 統一性 & 躍動性 \\
\hline \multirow{7}{*}{ 国 } & 建て込み & 0.428 & & & & & & \\
\hline & 水量 & 0.483 & 0.453 & & & & & \\
\hline & 満足意諳 & 0.583 & 0.472 & 0.404 & & & & \\
\hline & 快適性 & 0.553 & 0.452 & 0.363 & 0.713 & & & \\
\hline & 統一性 & 0.553 & 0.453 & 0.382 & 0.703 & 0.641 & & \\
\hline & 躍動性 & 0.462 & 0.311 & 0.362 & 0.572 & 0.580 & 0.501 & \\
\hline & 伝統性 & 0.043 & 0.049 & 0.062 & 0.041 & 0.017 & 0.139 & -0.085 \\
\hline \multirow{7}{*}{$\begin{array}{l}\text { 日 } \\
\text { 本 }\end{array}$} & 建て込み & 0.329 & & & & & & \\
\hline & 水量 & 0.500 & 0.234 & & & & & \\
\hline & 満足意諳 & 0.470 & 0.483 & 0.286 & & & & \\
\hline & 快適性 & 0.501 & 0.414 & 0.275 & 0.694 & & & \\
\hline & 統一性 & 0.362 & 0.392 & 0.174 & 0.597 & 0.547 & & \\
\hline & 筑篗梏性 & 0.246 & 0.063 & 0.106 & 0.268 & 0.284 & 0.197 & \\
\hline & 枟統性 & 0.137 & -0.008 & -0.004 & 0.103 & 0.180 & 0.146 & -0.060 \\
\hline \multirow{7}{*}{$\begin{array}{l}\text { 欧 } \\
\text { 州 }\end{array}$} & 建て込み & 0.290 & & & & & & \\
\hline & 水量 & 0.361 & 0.396 & & & & & \\
\hline & 洏足意識 & 0.517 & 0.524 & 0.437 & & & & \\
\hline & 快適性 & 0.515 & 0.478 & 0.428 & 0.609 & & & \\
\hline & 統一性 & 0.383 & 0.407 & 0.300 & 0.584 & 0.558 & & \\
\hline & 躍動性 & 0.278 & 0.007 & 0.201 & 0.284 & 0.296 & 0.182 & \\
\hline & 伝統性 & 0.170 & 0.336 & 0.043 & 0.321 & 0.348 & 0.456 & 0.224 \\
\hline
\end{tabular}

\section{1 自由観察時の注視特性}

景観という視覚刺激を呈示した際に、被験者はその中からまずさまざ まな情報を収集し、景観全体の特徵を認識したうえで、評価や判断を行 うものと考えられる。したがって、自由観察時の注視特性の把握は景観 の認識・評価プロセスを検討するにあたつて基礎的な段階を与えるもの と考えられる。本節では、既報 ${ }^{8)}$ との比較も想定し、自由観察時の注 視特性について注視点の分布性状から概括する。

実験 I における、被験者に景観を 15 秒間自由に眺めさせて測定した 眼球運動のデー夕に基づいて、被験者からみて横 33 度 $\times$ 縦 23 度の分 析対象範囲を 1 度刻みに分割し、得られた 759 の正方小領域ごとに注視 点数の累積值を求めた。なお、累積值の多少には各国の被験者数の違い や欠損值の有無等が反映されるため、各国間での比較にあたっては、日 本、中国の被験者数である 30 名に等しくなるよう累積値に補正を行つ た注 7)。中国、日本、欧州における、各景観についての注視点の平面的 な分布傾向を図一 5 に示す。また、注視点の分布をより定量的に把握す るため、各景観における注視点の座標值からX方向 (水平方向)、Y方 向（垂直方向）の標準偏差をそれぞれ求めた。結果を図一6に示す。

これより、全体的な傾向としては、いずれの景観においても、構成要 素の配置にしたがって注視点の分布する傾向が、中国、日本、欧州で共 通していることがわかる。X、Y方向の標準偏差の結果をみると、Y方 向では 2 国間の相関係数がいずれも 0.9 以上であるが、X方向では中国 と日本の相関倸数が高いのに対して、欧州では両国との相関係数が 0.5 〜0.6の值を示しており、若干違いがみられる。また、中国ではX方向 の標準偏差が全体的には日本より低いことから、既報 ${ }^{8)}$ と同様に、中 国は日本より景観の中央付近を観察する傾向があるといえる。

次に、実験に供した景観画像（600×400）を、横 30 度×縦 20 度に 

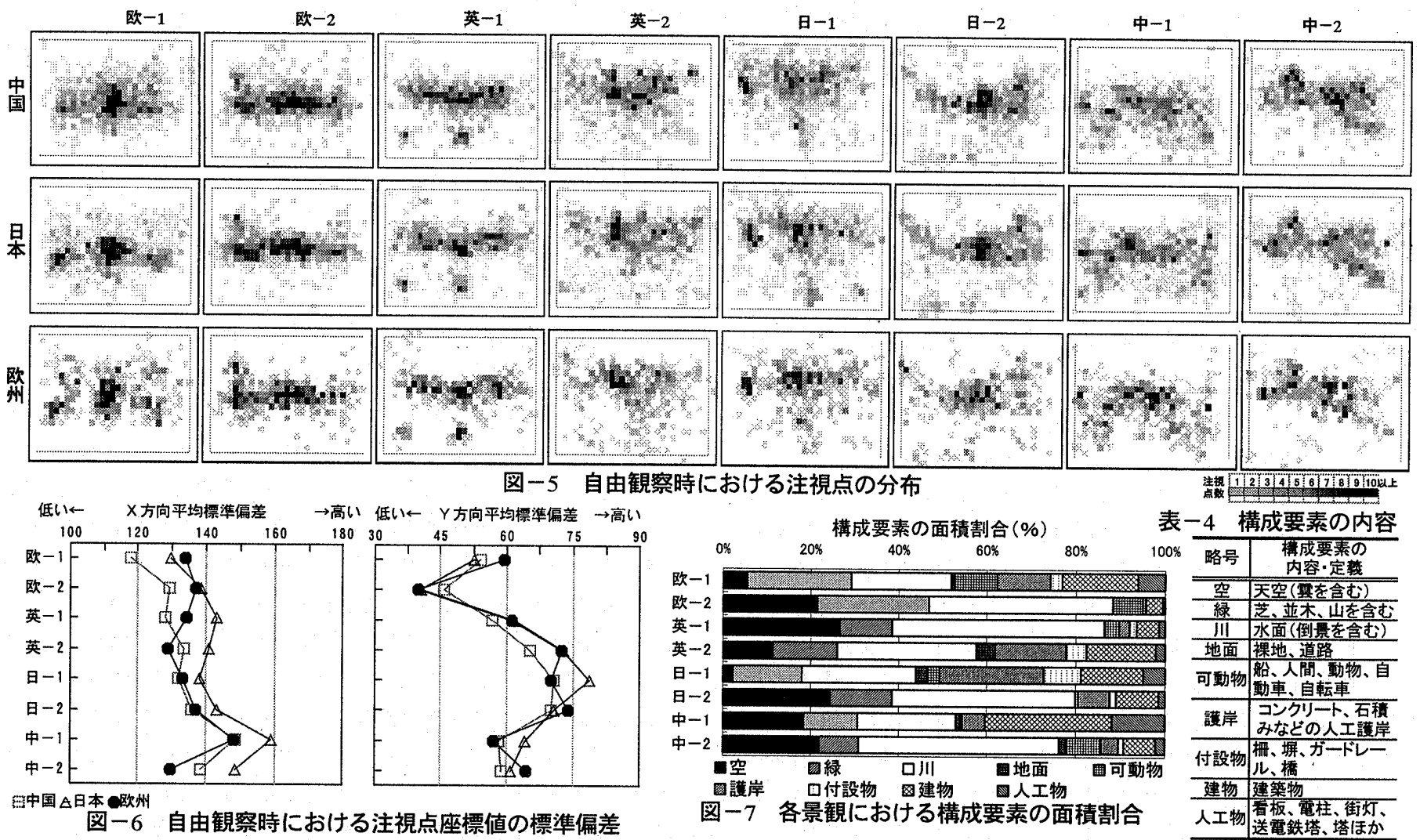

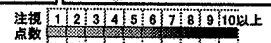

分割し、各小領域について、多くの面積を占める景観構成要素を選定し、 一つの小領域に対してそれぞれ一つの要素を対応させ、その小領域ごと の注視点数を集計することにより、各景観で具体的によく見られる要素 について検討する。構成要素は既報 ${ }^{3)}$ を参考に表一4に示す 9 要素とし た。なお、電柱や看板などの人工物や、椢、塀などの付設物については、 各小領域に多少なり含まれれば、その小領域はそれらの要素と定義した。 各景観における構成要素の面積割合を図一7に示す。いずれの景観にお いても、「川やや緑「建物」が多く、「人物」や護岸「可動物」などが少 ないことがわかる。

各景観について、それぞれの要素ごとに注視点数を算出し、中国、 日本、欧州の各国の平均值を求めた結果を図一8に示す。

全体的には、よく注視されている要素として「川」緑「建物つが举げら れ、次いで、可動物」や護岸」となる傾向が3国に共通している。また、 自動車や人間、船、動物などが河岸あるいは水面に散在している「欧一

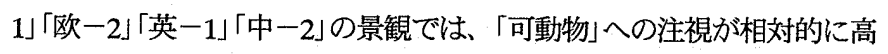
く、可動物がないあるいは少ない景観では、「建物「人工物」への注視が 増加する傾向が認められる。一方、3 国間の差異としては、欧州の被験 者は、全体的に注視点数が他の 2 国より少ない傾向を示し、「川いへの注 視が特に少ない。また、中国では「緑「「」「護岸」、日本では「可動物」「建 物へへの注視が他の 2 国より多くなっている。

さらに、各構成要素が景観に占める面積によって注視点数も変化する ことが考えられるため、注視点数と構成要素の面積割合との相関係数を 求めた。中国、日本、欧州それぞれの結果を表一 5 に示す。図一 8 と併 せてみると、「可動物」や「付設物」人工物」では相関保数が若干高いが、 「緑「川なな゙では面積劃合と注視点数はあまり関係なく、いずれの景観 においても注視点数がほぼ均等となる傾向が 3 国に共通することがわ かる。以上の結果から、景観に含まれる構成要素の面積割合が、要素に よっては注視点数に影響を及ぼすものの、いずれの国でも、関心がある

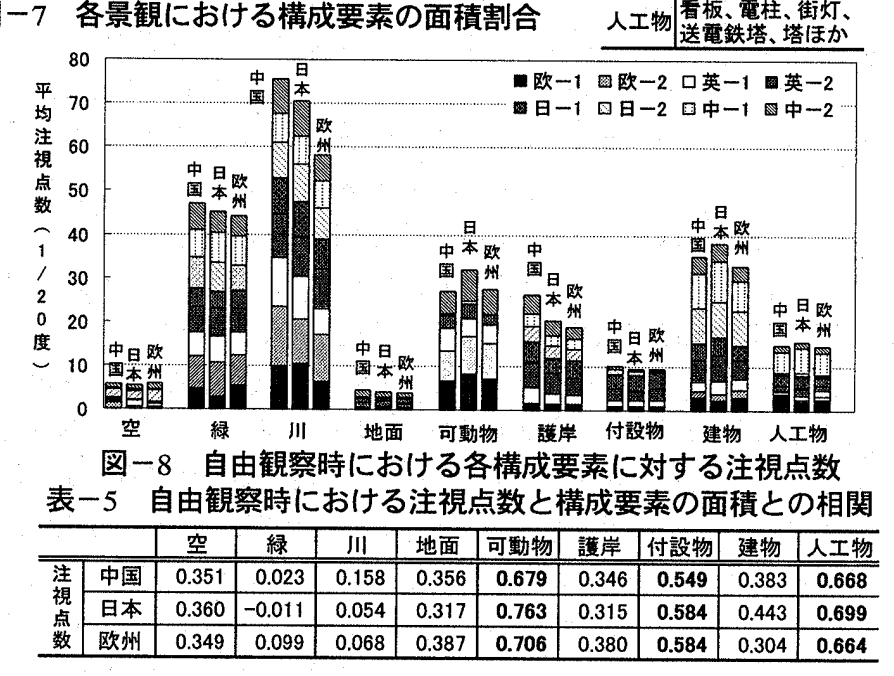

要素への注視によって景観の全容が把握·認識されていることがわかる。

\section{2 評価回答時の注視特性}

呈示した景観に対して、特定の心理的評価を求めた場合、被験者はそ の内容と関連する要素に注意して景観を観察し、これまで記憶された知 識や経験などと照合して評価を定めると考えられる。したがって、景観 中に含まれる各要素のいずれにもある程度の注意を向けることが予想 される自由観察時とは異なり、評価回答時には、被験者の有する認識・ 評価プロセスに従って目を動かしているものと予想される。これより、 本節では、評価回答時の注視特性について、出身国間て比較・検討を行 う。図-8 と同様に、各景観における構成要素ごとの注視点数の出身国 別の平均值を求めた。中国、日本、欧州それぞれについて 8 景観におけ る平均注視点数を合計した結果を図一9に示す注8)。

なお、被験者が景観の観察を開始し、評価を決定するまでが眼球運動 の測定時間となるため、実験 I と異なり、注視時間は一定ではない。し たがって、注視時間の長短による影響を避けるため、ここでは、出身国 


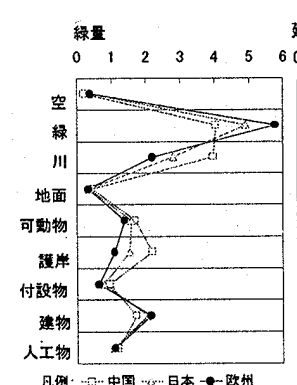

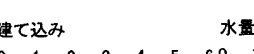

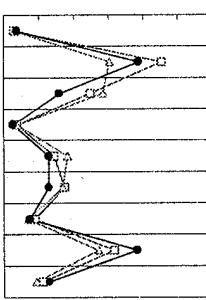

別、各評価項目別の平均注視時間によって注視点数を除している。注視 時間に関する詳細な結果はここでは割愛するが、3 国ともにほぼ 4.5〜 6.2 秒を要し、いずれの項目においても 3 国間の差は 0.1 0.7 秒と些少 であり、出身国による著しい差異は夕られなかった。

評価項目別にみると、『緑量』では、3 国ともに「緑」への注視が多い が、そのほかに「川やや建物」「可動物」「護岸」などへの注視もみられる。 これより、『緑量』を評価する際には、単純に緑の量的な側面だけでは なく、景観全体のバランスも考慮され、各要素への注視が分散する傾向 が把握できる。なお、「緑」への注視が日本と欧州では最も多いのに比し て、中国では「川」ほぼ同程度であり、景観ごとの注視点数の結果によ れば、緑の面積割合が高い景観でこの傾向が顕著に認められる。また、 中国では護岸」の注視点数も他の 2 国より多く、緑の量的な側面のほか、 河岸での存在形態や川との位置関係なども判断に関与する可能性を示 唆した心理的評価結果に基づく推測を裏づける結果が得られた。

『建て込み』では、「建物」や「緑」が 3 国ともに多く注視される傾向を 示すが、日本と欧州では、「建物」が「緑」とほぼ同程度に注視されている のに対し、中国では「緑」の注視点数が「建物」よりかなり多くなっている。 中国では心理的評価で『建て込み』と『緑量』との相関がみられたこと から、緑の量や存在形態などが『建て込み』の評価においても判断の基 準としてよく注視されるものと考えられる。

『水量』では、出身国による傾向の差異はほとんどみられない。水量 と直接関連する「川」への注視が圧倒的に多く、「護岸」や、船などの「可 動物」への注視も多少みられることから、いずれの出身国の被験者も、 水面の広がりを中心に観察するとともに、川と護岸とのバランスや船舶 の航行可能性 (水深の深浅) なども考虑しているものと考えられる。

『満足意識』と『快適性』においては、中国では両項目ともほぼ共通 の傾向を示し、「緑」への注視は他の 2 国とほぼ同程度であるが、「川」 や「護岸」への注視が他の 2 国より多くなっている。河川に対する「治水 面」利水面」への関心が高いことと関連し、中国は緑の量や存在形態よ り、むしろ川の流れや水質、あるいは、河岸との対応関係による河川の 全体的な整備状況などをより重視して観察していることが予想される。 これに対して、日本と欧州では、『満足意識』は中国と同様に「川への 注視が最も多く、次いで「緑」であるが、『快適性』では、「緑」への注視 が「川より多くなっている。

また、欧州では、『満足意識』『快適性』とも「建物」の注視点数が他の 2 国より多く、景観ごとに求めた結果によれば、この傾向は日本と中国 の景観で顕著に認められる。これは、心理的評価結果において、『伝統 性』と『満足意識』との相関が欧州でみられたこと、また、中国や日本 の文化に対する知識がやや劣ることなどから、見慣れない景観に対して 特に建物の様式や意匠、歴史性に関する観察が増えるものと考えられる。

『統一性』では、「建物」「緑」への注視は3国間で共通するが、「川「可 動物」では多少の差異がみられる。心理的評価では、3 国とも建物の意
快遥性統一性踏動性統性

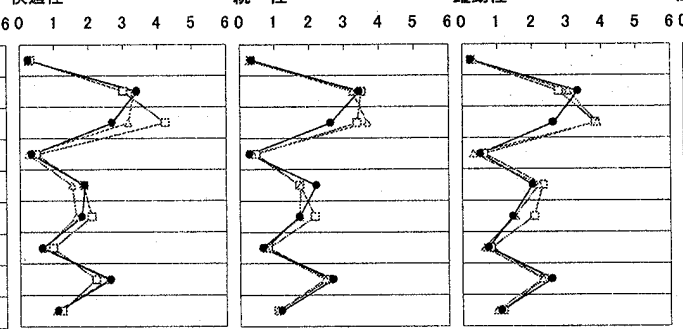

$\begin{array}{lllllll}60 & 1 & 2 & 3 & 4 & 5\end{array}$

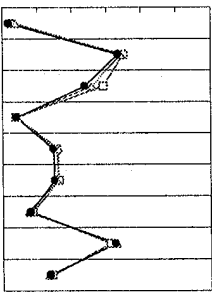

\section{情成要素に対する平均注視点数}

匠や景観全体の色彩調和などの影響が予想されており、「建物」や「緑」 と併せて「川への注視も多いことから、欧州に比べ日本や中国ではより 景観全体の要素の調和が意識されているものと考えられる。

『躍動性』では、3国に共通して「可動物」への注視が他の評価項目よ り多くなっている。なお、欧州と比して中国と日本では「川への注視が 多くなっているが、水面にある可動物のほか、水面の状態や流れなども 『躍動性』を判断する際の要因として考慮されているものと考えられる。

『伝統性』では、各要素への注視傾向は3 国間でほぼ一致しており、 評価之直接関連する「建物」のほか、「川「緑〕人工物「「可動物」などへの 注視が『建て込み』と類似した傾向を示している。建物の様式や、建物 の周辺に設置されている看板や街灯などとの調和について観察すると ともに、景観の全体的な雾囲気も考慮している傾向が 3 国間で共通する ものと考えられる。なお、「緑」が「建物」とほぼ同程度に注視されている が、緑の背後に建物が存在する景観が多いことから、建物を観察する際 に、緑への注視も生じたものと考えられる。

以上の結果を、図ー8の自由観察時の注視特性に関する結果と併せて まとめると、『満足意識』における各要素への注視の多寡が自由観察時 とほぼ類似する傾向が 3 国ともに共通してみられ、総合的な評価は景観 中に含まれる各要素をいずれもある程度観察し、景観全体の特徵を把握 したうえで判断されるものと考えられる。なお、『水量』以外の評価項 目では、「空」「地面」「付設物」人工物」への注視は自由観察時の注視とほ ぼ同程度であるが、建物」「可動物」「川」緑」「護岸」では評価項目によっ て注視の多塞に変化が生じている。また、自由観察時は、景観全体の情 報を収集するため、出身国の違いに関わらず注視特性がかなり共通して いるが、評価回答時においては、項目によっては異なる傾向を示すこと があり、今までの生活体験や、出身国の自然的な環境などと比較して景 観を観察し、文化の違いによって認知の仕方が異なることが示唆される。

\section{5. 心理的評価に及ぼす注視特性の影響の検討 \\ 5. 1 注視点数と心理的評価との相関}

本章では、前述した景観に対する心理的評価と評価回答時の注視 特性の結果を用いて、両者の関連性について、異なる出身国間で比 較を行う。まず、心理的評価を行う際に、ある要素に対する注視の 多賽が評価に及ぼす影響を検証するため、各評価項目の平均評価得 点と、対応する項目を評価させた時の構成要素別の平均注視点数之 の相関係数を求め、心理的評価と注視特性との関連性について概括 する。8 景観をサンプルとして求めた中国、日本、欧州それぞれの 結果を表一6に示す。

これより、いずれの国においても、「建物」や「人工物」と高い相関 を示す評価項目が多くみられ、さらに、これらの相関係数が負の值 であることから、建物やその周辺にある看板、柵などの人工物が着 目され、よく注視される場合、心理的評洒に負の影響を与えること 
が予想できる。また、「川」や「可動物」では多くの項目と正の相関を 示しており、特に河川の「親水面」への関心が強い欧州では、「可動物」 で全ての項目と 0.3 以上の相関が得られている。川の流れや形態、 舟運の機能、人との接触などが着目される場合、評価が向上するこ とが推測できる。なお、「地面」では多少の相関を示す項目が欧州で 若干現れているものの、「付設物」を含めて、中国や日本と同様に、 相関係数は全体的に低くなっている。また、「緑」との相関を示す評 価項目は、日本と欧州では少ないが、中国では多く挙げられており、 緑への着目の程度が評価に影響を及ぼしていることがうかがえる。

\section{2 心理的評価に及ぼす注視特性の影響}

前節の結果から、景観に含まれる要素への注視の多塞は心理的評価 とある程度の関連を有することを検証した。ただし、相関係数の算出に 用いた心理的評価と注視点数はいずれも景観ごとの平均值であること から、一般的な傾向を示す結果とみなせるものの、ある景観のある要素 に対して、全ての被験者が同じように注視するとは考えられない。した がって、個人ごとの注視特性を用いたより詳細な分析が必要となる。

本節では、異なる出身国間で心理的評価に及ぼす注視特性の影響を仔 細に把握するため、被験者個人ごとの注視特性と心理的評価を用いて両 者の関連を検討した。具体的には、各評価項目を外的基準、実験 II の結

表-6 注視点数と心理的評価との相関

\begin{tabular}{|c|c|c|c|c|c|c|c|c|c|c|}
\hline & & 垔 & 緑 & $\pi$ & 地面 & 可動物 & 酽崖 & 付設物 & 建物 & 入工物 \\
\hline \multirow{8}{*}{ 中 } & 線量 & 0.829 & 0.479 & 0.490 & -0.109 & 0.417 & -0.002 & -0.085 & -0.791 & -0.400 \\
\hline & 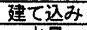 & 0.743 & 0.787 & 0.632 & 0.202 & 0.582 & 0.418 & 0.124 & -0.215 & -0.592 \\
\hline & 水量 & -0.018 & 0.185 & 0.101 & -0.167 & 0.513 & -0.750 & -0.042 & 0.003 & -0.229 \\
\hline & 満足意識 & 0.383 & -0.136 & 0.288 & 0.114 & 0.172 & 0.133 & 0.042 & -0.565 & -0.731 \\
\hline & 快適性 & 0.563 & 0.835 & 0.795 & 0.205 & 0.177 & 0.343 & 0.194 & -0.526 & -0.764 \\
\hline & 統一性 & 0.408 & 0.545 & 0.350 & 0.118 & 0.023 & 0.243 & 0.069 & -0.432 & -0.770 \\
\hline & 霍動住 & 0.447 & 0.388 & 0.751 & -0.140 & 0.434 & -0.112 & -0.112 & -0.250 & -0.578 \\
\hline & 伝統珄 & -0.415 & -0.707 & -0.168 & 0.396 & 0.325 & 0.312 & -0.198 & -0.115 & 0.384 \\
\hline \multirow{8}{*}{$\begin{array}{l}\text { 旦 } \\
\text { 足 }\end{array}$} & 線量 & 0.535 & 0.384 & -0.293 & -0.230 & 0.620 & -0.182 & -0.150 & -0.520 & -0.489 \\
\hline & 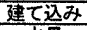 & 0.130 & 0.127 & 0.433 & 0.352 & -0.131 & 0.503 & 0.333 & -0.221 & -0.931 \\
\hline & 水量 & 0.411 & 0.306 & -0.176 & 0.034 & 0.614 & -0.681 & -0.565 & 0.155 & -0.413 \\
\hline & 满足意織 & 0.454 & 0.207 & 0.738 & 0.068 & 0.131 & 0.017 & 0.098 & -0.556 & -0.817 \\
\hline & 快適性 & 0.209 & -0.312 & 0.804 & -0.043 & 0.254 & -0.069 & -0.026 & -0.875 & -0.652 \\
\hline & 統一性 & 0.255 & -0.131 & 0.637 & 0.247 & 0.343 & 0.170 & -0.076 & -0.788 & $\frac{0.658}{-0.658}$ \\
\hline & 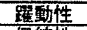 & 0.208 & -0.331 & 0.359 & -0.092 & 0.634 & -0.259 & -0.150 & -0.516 & -0.041 \\
\hline & 伝統性 & -0.530 & -0.045 & -0.161 & 0.205 & 0.353 & 0.107 & 0.255 & -0.051 & 0.190 \\
\hline \multirow{8}{*}{ 欧 } & 線量 & 0.282 & 0.457 & -0.041 & -0.424 & 0.863 & -0.483 & -0.371 & -0.726 & -0.723 \\
\hline & 建て込み & 0.266 & -0.044 & 0.455 & 0.436 & 0.430 & 0.455 & -0.041 & -0.330 & -0.330 \\
\hline & 水量 & -0.253 & 0.057 & -0.144 & 0.118 & 0.642 & 0.447 & -0.041 & -0.004 & -0.425 \\
\hline & 满足意識 & -0.016 & 0.367 & 0.228 & -0.058 & 0.602 & -0.213 & -0.276 & -0.637 & -0.878 \\
\hline & 快適性 & 0.012 & 0.342 & 0.811 & 0.128 & 0.385 & -0.132 & 0.020 & -0.891 & -0.607 \\
\hline & 統一性 & -0.041 & 0.235 & 0.693 & 0.443 & 0.356 & -0.016 & 0.137 & -0.866 & -0.669 \\
\hline & 翟動性 & 0.053 & -0.436 & 0.613 & -0.426 & 0.816 & -0.479 & -0.245 & -0.657 & -0.188 \\
\hline & 伝統性 & -0.668 & 0.019 & -0.159 & 0.389 & 0.301 & 0.227 & -0.409 & -0.459 & -0.108 \\
\hline
\end{tabular}

果から算出した各構成要素の注視点数 (以降では注視要素と称する)を 説明変数とし、景観×被験者をサンプルとする判別分析を行った。表 -7に各項目における各要素の偏相関係数による結果を示す。なお、 表中の注)に示すように、各項目に対する 5 段階尺度の回答は、それ ぞれ 2 カテゴリーにまとめている。また、表一 4 に示す 9 つの構成 要素のうち、「地面」「付設物」に対する注視点数は、前節の結果で心 理的評価とほとんど相関がみられないことから、「護岸」と併せて「付 設 $2 」$ に統合し、他の 6 要素と合わせて 7 要素を注視要素とした。

全体的にみると、『緑量』と『水量』は、中国では相関比が若干 低く、景観中に含まれる構成要素の量的な評価は、単純にある要素 への注視の多寡による影響を受けるとは断言できないと考えられる。 また、『伝統性』においても、3 国ともに低い相関比を示しているこ とから、建物やその周辺の看板や人間などの要素に対する注視の量 だけではなく、建物の形状や様式など、着目する要素の内容がより 影響するものと考えられる。以下、偏相関係数の值から、異なる出 身国間で評価に影響を及ぼす注視要素の異同について考察を行う。

景観における物理的特性との関連が強いと考えられる『緑量』 『建て込み』『統一性』では、それぞれ「緑」人工物〕建物」と、特定 の注視要素の影響が、欧州や日本でみられる。これに対して、中国 では、むしろ景観に含まれる多様な要素への注視によって評価が左 右されるものと考えられる。また、『水量』では、注視点数が顕著に 多い「川」の偏相関係数は意外に低くなっている。景観中に占める 水面の割合が大きいことから、注視点数の多少はむしろ水面の表情 や倒景などによって左右されることが予想され、評価と注視要素と しての「川」の間には、3国ともにあまり関連は認められない。

『満足意識』では、「人工物」建物」への注視が 3 国ともに評価に 負の影響を与える傾向が前節と同様に認められ、特に「人工物」の影 響が大きい。出身国の違いにもかかわらず、よく着目される（気に なる）人工的な建造物の存在が満足度の評価を低下させるものと考 えられる。快適性』では、3国に概ね共通して、「建物」や「人工物」

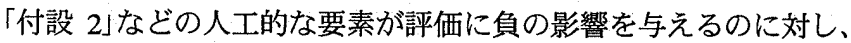
「可動物」や「川などの要素がよく着目される場合に評価が向上する 視点数との関連

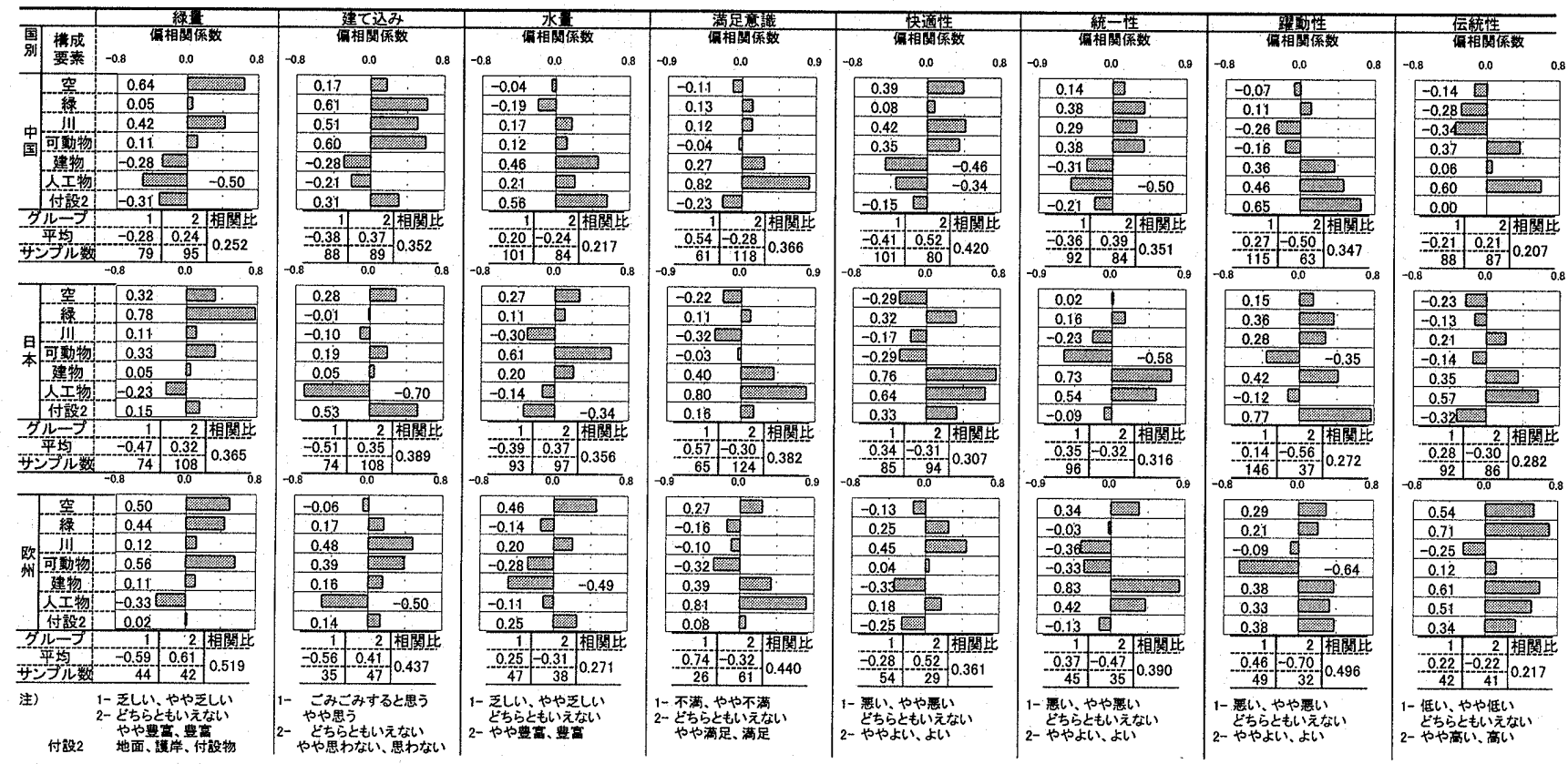


ことがわかる。なお、心理的評価では 3 国間でこの 2 項目において 類似した評価傾向が得られたが、ここでは、評価を向上させる注視 要素に多少の違いがみられる。『快適性』と比べ『満足意識』では、 「人工物」による影響がより顕著ではあるものの、他の注視要素によ る影響は相対的に低いことから、評価を向上させるのは各要素に対 する単純な注視の頻度ではなく、注視要素の内容という質的な側面 であると考えられる。すなわち、『満足意識』では、個人の暂好や生 育環境の自然形態、あるいは、これまでの生活習慣など総合的な要 因による影響のより強いことが予想される。

『躍動性』について、河川の「親水面」に関心が強い欧州の被験者 は人との親しみの程度が考慮され、「可動物」への注視による影響が 現れるが、中国と日本では建物や護岸の様式、河岸に付設された柶 や塀の形など人工的な建造物の存在がより考慮され、それらの要素 への注視による影響がみられる。

以上の結果から、客観的な情報として取得される景観の物理的特 性との関連がみられる『緑量』『建て込み』などの項目では、心理的 評価では評価傾向が共通しているにもかかわらず、注視要素による 影響が出身国によって多少異なることが示された。また、『満足意 識』や『快適性』など景観全体の総合的な評価項目では、評価に負 の影響を及ぼす注視要素はほぼ共通しているが、評価を向上させる 注視要素については、社会・文化的背景の違いによって両項目間で 異なることが示唆された。

\section{6. 結語}

本研究では、評価者の社会・文化的背景が景観評価に及ぼす影響 をより明確に把握するため、異なる出身国の被験者に対して、アイ カメラによる眼球運動の計測を含む心理的評価実験を実施し、社 会・文化的背景の相違が景観の認識・評価に及ぼす影響について検 討を行った。得られた知見をまとめて以下に示す。

1) はじめに、呈示した各河川景観における総体的・個別的評価お よびイメージ評価について、平均評価得点を算出し、『緑量』や『水 量』など景観の物理的特性に関する個別的評価では、中国、日本、 欧州の 3 国間の評価傾向の共通性が高いが、『満足意識』や『快適 性』など総合的評価項目では、3 国間で差異が生じることを既報 ${ }^{3)}$ と同様に示した。さらに、各評価項目間の相関係数を求めた結果 から、欧州では、既報 ${ }^{3)}$ と同様に『伝統性』が景観の総合的評価 に影響を及ぼすことを明らかにした。

2）次に、呈示景観に対する認識・評価について、異なる出身国間 で注視特性の差異を検討するため、景観を自由に観察させた時の 注視点の分布、注視点の中心からの広がり、各構成要素別の注視 点数をそれぞれ求めた。その結果、出身国の違いにもかかわらず、 景観に対する認知の仕方がほぼ共通することを示した。

3）心理的評価に対する回答と同時に測定した注視特性については、 各評価項目に対する注視点数を構成要素別に求め、「付設物」や「人 工物」空」などでは評価項目によらず、ほぼ共通した注視点数とな るが、「川」や「緑」「可動物」などでは評価項目によって注視の多塞 が異なり、3 国間でも差異が生じることを示した。

4) 最後に、評価に対する構成要素別の注視点数と評価との相関を 求め、心理的評価と注視特性とが関連を有することを確認した。 さらに、各心理的評価を外的基準とし、各評価における構成要素
別の注視点数を説明変数として判別分析を行い、同様な心理的評 価結果であっても、影響を及ぼす注視要素が異なり、社会・文化 的背景の違いによって認知の仕方にも差異の生じる可能性のある ことを指摘した。

\section{【謝辞】}

本研究の一部は、平成 13 年度日本建築学会中国支部奖励研究助成金(代表 : 金華)によったことを記す。さらに、実験にご協力頂いた広島大学の日本人大学 生および中国、欧州出身の留学生、広帛経済大学の欧州出身の留学生の方々に 謝意を表する。また、実験およびデー夕集計の一部にご協力頂いた広島大学平 成 13 年度卒論生橋本暢登君に謝意を表する。

【注】

1) 眼球運動測定に用いたアイカメラは、計測時に頭部が動くことによって出力 座標値にズレが生じる。これをなるべく少なくするため、被駼者の頭部はで きるだけ静止させた状熊で保持する必要がある。本研究では、アイカメラを 被験者の頭部に装着した後、被験者の顎を事前に用意した台の上に載せ、頭 部を固定させたため、質問に対して発話による回答は禁じ、手の合図によっ て回答することとした。

2) 同一の景稩や啠問が連続しないよう、8種類の異なる景観に対して、8 項目の異な る心理的詊価をランダムに割り当てた、景観と評俩の 8 対の組合せを1ステージ とし、呈示にあたってはその中で対の順序をランダムに変化させた。したがって。 実験全体では、このようなステージを8回繰り返すことになる。

3）本研究の心理的評価に用いたイメージ評伯項目は、既報 ${ }^{3}$ の 25 形容詞対に 基づいて抽出された因子構造から選定したため、被験者にはその因子内容を 決定づける代表的な形容詞をいくつか選定して質問した。すなわち、『快適 性』について尋和る場合には、「景観全体の『快適性』に対して、例えば:爽 やかさや、安らぎ、自然の豊富さ、好き嫌いなどの面からごう感じられます か?」のようにした。また、他のイメージ評価項目の評定に用いた形容詞は、 『統一性』が、調和した、統一的な、整然としたの3 形容詞、『躍動性』が、 活発な、荒々しい、速い、華やかなの 4 形容詞、『伝統性』が、伝統的な、新 しいの 2 形容詞である。

4) 本研究では、被験者の疲労等、実験上の制約から呈示景観数を 8 種としてい る。相關係数の算出にあたって、サンプル数8はやや少ないと考元られるが、 全体的な評洒パターンの類似性を判断するのに適当な指標であるため、分析 手法として採用した。なお、サンプル数8 の無相関検定における䟢界值（片 側検定）は、有意水準 $5 \%$ で $0.621 、 1 \%$ で 0.789 である。

5)「世界各国要覽 データブック 1999」よよると、各国の森林の面積割合において、 欧州は $41.3 \%$ 、日本は $66.2 \%$ 、中国はわずか $13.6 \%$ である。

6) 既往研究 6)、クでは、アイカメラから出力される連続的な視点座標值のデー 夕処理にあたって、一定時間間隔でデータを区分して用いたり、視点の移動 速度がある值以下の場合に注視していると判断するなど、多くの提案がなさ れているが、本研究では、視点が一定時間以上、一定の円形範囲内に停留し たときに、この䈥冊の中心座標を注視した点 (以降、注視点) とする方法を 採用する。サンプリング間隔 1/30 秒でアイカメラより出力された座標データ の変換過程としては、まず補正用スライドの四隅に対する座標值を補正值と して用い、アイカメラから直接出力された座標テー夕について、三次元射影 変換を施した。なお、影観呈示前後それぞれの補正值によって2 種類の変換 結果が得られるが、構成要素の位置などとの対応から、実態をより正確に反 映していると考えられるいずれか一方を採用する。さらに、分析範围外のデ 一夕を不正データとして除外する。ただし、分析対象籁囲としては、スライ ド映像外縁付近の注視も想定されることから、横 30 度X維 20 度のスライド 映像の領域加ら上下左右に各 1.5 度外側まで、すなわち、横 33 度×緹 23 度 の篹囲とした。最後に、前述の定義に基づいて注視点を決定する。本研究は この最終的に得られた注視点デー夕をもとに考察を進める。

7) 例元ば欧州の場合、被験者数 14 名であるから、累積值に30/14を乘じている。

8）景観ごとに各構成要素の面積比は異なり、表一5に示すように平均注視点数 の多少にも、その影響が少なからず反映されている。したがって、8景観を サンプルとして $\mathfrak{t}$ 一検定等の統計的手法を適用する場合、注視点数の分散に はこの要素の面積比による変動も含まれることから分散が過大になり、検定 力の低下する恐扟があるため、ここでは $\mathrm{t}$ 一検定等の検定は適用していない。

\section{【参考文献】}

1）西名大作，村川三郎，金 華: 東広帛市における留学生の生活環境評価に関する研 究, 日本建筑学会計画系論文集，第529 号,pp. 101-108, 2000年3月

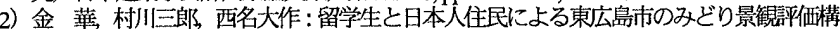
造の比較、日本建筑学会計画係論文集，第544 号, pp. 47-54,2001年6月

3）金 華，西名大作，村川三郎，飯尾昭彦：英国·日本·中国の被験者による河川景観 評価構造の比較分析, 日本建留学会計画系論文集，第 544 号, pp. 63-70,2001 年 6 月

4）藤井英二郎，安藤敏夫，金 恩一: 植物の色彩と眼球運動及乙脑波との関わりにつ Wて, 造園徐誌第 57 号, pp. 139-144, 1994 年

5）古谷勝則, 油井正昭, 沼本健司, 裴 重南, 览島隆政: 自然景観における建築物の

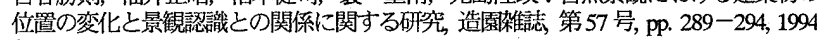
年

6）村川三郎，西名大作，植木雅浩：河川景観の画像特徴量と被験者注視点の関連，日 本建筑学会計画孫論文集、第 479 号, pp. 67-76, 1996 年1月

7) 村川三郎, 西名大作, 植木雅浩, 横田幹朗河川景観の画像特徵量之被験者の心理的 評価構造の関車，日本建築学会計画係論文集，第 524 号, pp. 53-60,1999年 10 月

8）西名大作，村川三郎，金 華，大石洋之：中国・日本の被験者による地域景観の注 視特性之評価構造に関する分析，日本建築学会言十画系論文集，第557 号, pp. 103-110, 2002 年 7 月

9）苧阪良二, 中溝幸夫, 古賀一大: 眼球運動の実験心理学, 名古屋大学出版会, 1993 年 